$\begin{array}{r}\text { Volume and Issues Obtainable at Center for Sustainability Research and Consultancy } \\ \text { Journal of Business and Social Review in Emerging Economies } \\ \text { ISSN: 2519-089X (E): 2519-0326 } \\ \text { Volume 6: No. 4, December 2020 } \\ \text { CSRᄃ } \\ \text { Journal homepage: www.publishing.globalcsrc.org/jbsee } \\ \hline\end{array}$

\title{
Sectarianism in Pakistan: A Statistical Analysis of Problems of Shia Hazara Community of Quetta
}

${ }^{1}$ Gulshan Majeed,

${ }^{1}$ Assistant Professor, Department of Political Science, University of the Punjab, Lahore, Pakistan, gulshan_99@hotmail.com

\begin{tabular}{l} 
ARTICLE DETAILS \\
\hline History \\
Revised format: November \\
2020 \\
Available Online: December \\
2020 \\
\hline Keywords \\
sectarianism, integration, \\
Shia Hazara Community, \\
Militant, Violence
\end{tabular}

JEL Classification M10, M11

(1)

\section{OPEN ACCESS}

Pakistan was created on the name of religion and it was perceived by the leaders that religion would prove a binding factor among various ethnic and religious identities of Pakistan but it could not happen because religion was not implemented in its true sense. The phenomenon of sectarianism emerged as a significant issue specifically during the decade of 1980s in the era of General Zia because of Islamization process. Quetta, the city of Balochistan has largest Shia Hazara community and this community has become victim of Suicide attacks, bomb blasts and terrorist acts. This community feels itself highly insecure in Quetta. Researcher has conducted research on this sensitive issue of sectarian violence against Shia Hazara community of Quetta by using primary and secondary sources to collect data. This study will highlight actual grievances of this community and provide guidance to the policy makers to understand the real concerns of this community.

(C) 2020 Center for Sustainability Research and Consultancy Pakistan under a Creative Commons Attribution-NonCommercial-ShareAlike 4.0

Corresponding author's email address: gulshan_99@hotmail.com

Recommended citation: Majeed, G. (2020). Sectarianism in Pakistan: A Statistical Analysis of Problems of Shia Hazara Community of Quetta. Journal of Business and Social Review in Emerging Economies, 6(4), 1611-1620

\section{Introduction}

Sunni-Shia conflicting situation is not new in Pakistan particularly in the province of Punjab. Sunni-Shia conflicts were of different nature under Britishers than the Muslim rulers in Sub-Continent. British Raj became successful to uproot sunni-shia confrontation during its whole period of governance from 1857 to 1947. They implemented variou policies to contain Sunni-Shia conflicting situation. After 1947 Shia in Pakistan tried to continue the attitude of indifference towards their faith as they used to do under Britishers. (Ahmad, 2011). Sectarian conflicts became more prominent during the decade of 1980. A number of internal and external reasons were there. Some external forces for example the Iranian Revolution also contributed in the emergence of sectarian violent conflicting situation in Pakistan. The growth of Shi'ite militancy in Iran proved a source for Shia community of Pakistan to assert them more forcefully and this assertion gave air to the existing differences between Shia and Sunni community of Pakistan. Ruling elite remained unable to establish socio-political institutions on the basis of true democratic and moral values. (Jullundhri, 1998). In the capital city of Balochistan different sects used to live peacefully but the peace of province was disturbed because of war in Afghanistan and Iranian 
Revolution.` Quetta the capital of Balochistan has largest Shia population between 500,000 and 600,000. They spread over in the west and east of the city. Since 1947, the Shia Hazaras community has remained an underprivileged. Mostly their income depends on remittance payments from Australia, Europe, Iran, and Gulf. This is one belief in Pakistan that Shia Hazara community receives Iranian support and General Zia's government permitted state actors to support anti-Hazara segments for this reason. (NHRC Report. 2018). Hazara Democratic Party is an organized voice of Shia Hazara community of Balochistan. This party is a significant source to find statistics on anti-Hazara violence in the capital city of Balochistan. The socio-economic condition of Pakistan also produces militant behavior among different sects. The country has been facing the menace of poverty since its birth and has a high population growth rate. One can observe socio-political fabric of the country ripped by corruption, poverty, illiteracy, and terrorism and most crucial by sectarian conflicts. The people of Pakistan seem highly worried about the future of Pakistan. In Pakistani society the phenomenon of radicalism has been working on sectarian lines. (Mahmood, 1995)

\section{Literature Review}

To review literature is very important to conduct research in an organized way. Researcher can have an opportunity through available literature review regarding topic to evolve a mechanism to conduct research in an impartial way. There can be more conceptual clarity and more valuable conclusions can be drawn which can be more helpful to solve problems of the society and state. For this present study researcher has tried to go through various available resources to develop conceptual clarity.

Khalid Ahmad in his book titled "Sectarian War: Pakistan Sunni-Shia Violence and Its Links to the Middle -East" has explained that thousands of lives have been lost in Pakistan because of sectarian conflicts. He states that during British Raj very tolerable level of Sunni-Shia tension was witnessed and this situation remained in Pakistan till the decade of 1970s. Sunni-Shia conflicts became explicit during 1980s due to role of certain internal and external factors. Pakistan became front line state during Soviet invasion in Afghanistan Islamization process which provided by General Zia within the boundary of Pakistan also was supported by the government of Saudi Arabia.

Musa Khan Jalazai in his book titled "Sectarianism and Politico-Religious Terrorism in Pakistan" has explained in detail administrative structure before partition and highlights the structure of Pakistan administrative system 1973 to 1985 . Author discusses ideological confrontation in religious perspective and organized sectarianism in Pakistan. He has explained in detail the differences among Sunni and Shia sects and their different tactics to respond each other and create terror in the society.

Anatol Lieven in his book titled " Pakistan a Hard Country " has explained in detail Pakistan's internal problems and threat to Pakistan from Pakistani Taliban. Author has discussed about different activities of Pakistani Taliban and their support base in Pakistani society. Pakistani Taliban enjoy support by the local population. Security forces find it very difficult to sort out their hide outs because they have been living like common people among general public. They initiate their disruptive activities and seek hide among local population.

Musa Khan Jalazai in his book titled "Suicide Terrorism Taliban, Cross-Border Terrorism and Violence in Pakistan and Afghanistan" has explained that terrorists target people indiscriminately and they initiate terrorist acts to achieve their specific objectives. The major objective of terrorists is to create fear in the mind of people and get government's attention. He did highlight the concerns of US and Afghanistan. It is the main concern of Afghanistan that Pakistan should prevent terrorists to cross over into Afghanistan. Escalation of militant extremism in Pakistan has created a significant fault line in the politics of Pakistan. Author explained that sectarian forces have potential to shake the foundation of state. Extremist elements have been posing great internal security threat. 
Zahid Hussain in his book titled "The Relentless Rise of Islamic Militants in Pakistan -And How It Threatened the World The Scorpion's Tail" has explained how and in what way Americans have been initiating various activities to fight against the militant groups of Pakistan and Afghanistan. He has highlighted in detail the concerns of America in this region. Author explained in detail about drone attacks Campaign to tackle extremist elements of Pakistan. Author has explained various issues related to drone attacks and reaction of local population because according to local population some innocent people have also becoming victim of these attacks and developing sense of hatred towards security agencies. Author did highlight that militants have secured safe heavens in different parts of Pakistan including the province of KPK, Baluchistan and Punjab.

Rashid Ahmad (Jullundhri) in his book titled "Islam and Current Issues" has explained in detail about the impact of Islamic fundamentalism in Pakistan. In Pakistan various social organization, Ulama, fundamentalists and nationalists want to bring change in socio-political set up. These groups share national feelings that Pakistani people should have a healthy political system which can secure their material and spiritual needs. Consequently people have to face hard times. They received bad treatment at the hands of ruling class. The author has explained the case of East Pakistan crisis.

Tor H. Aase in his article in the book titled "Muslim Diversity: Local Islam in Global Context" has explained in an organized way the existing differences between Sunni and Shia of Gilgit. Before 1988 Gilgit used to be perceived a peaceful place where Shia, Sunni and Ismailis have been living peacefully without confronting with each other. In 1988 conflict emerged between Shias and Sunnis over the start of Ramadan. A single incident did happen which escalated into violent conflicting situation beween Sunnis and Shias of Gilgit particularly and generally in whole. Shias start their fast one day before Sunnis and same was done by the Shias of Gilgit. On the second day of Ramadan Shias of Gilgit woke up and anti shia slogans written on the walls of towns. The writings claimed that Shias were non Muslims or Kuffar. Shias became highly emotional over these writings and shooting broke out. Sunnis from the south of Gilgit started to move to rescue their fellow believers. Sunnis were moving to wage jehad on Shias in Gilgit and Shias were also gathering to fight against the Sunnis. Conflict became so violent that government has to ask.

Huma Yousaf in her report Titled "Sectarian violence; Pakistan Greatest Security Threat" Author has explained that Pakistan has faced a sharp resurgence in sectarian violence. This sectarian violence can be inter-faith and inter-sect. In inter-faith violence non Muslim communities like Hindus, Christians, Sikhs and parse's are made target. In sectarian conflicts the Deobandi practice the most orthodox version of Islam and are most extremist group against Shias. They have established madras's in country and developed relations with Taliban. She has highlighted the emergence of sectarian conflicts in more forceful way during Zia regime. The role of external actors' cannot be ignored in this regard. Musharraf during his regime imposed ban on different sectarian and militant organization but after 9/11 the policies of government gave air to the resurgence of sectarian violence. She has suggested various policies to curb the menace of sectarian violence. The government has to impose strict ban on sectarian outfits and provide security to those judges who involve in trial of sectarian criminals and restricting funding to sectarian groups. Farman Ullah in his article titled "Sectarianism in Pakistan: Causes \& Remedies (Pakistan No 43\&44 Spring \&Autumn 2009) has explained in a comprehensive way about the concept of sectarianism and its strong hold in Pakistani society. According to author Religion in Pakistan is used by the religious, political and military force as a card to grab power. First phase of the sectarianism started in Pakistan from 1947 and remained till 1977. During this era, sectarianism escalated because of many reasons. Zia's Islamization further added intensity in this whole process.

Asma Khan Mahsood in this article titled "History of Sectarianism in Pakistan: Implications for Lasting Peace (Journal of Political Science \& Public Affairs Vol.5, Issue 4. 2017) has explained about the historical background of sectarianism, social, political and economic implications of sectarianism on the 
Pakistani society. Islam is the religion of peace and tolerance. Pakistan was established on the name of Islam so is called as the country of peace and love. Before 1980, issue of the sectarianism was not a major problem but due to the Islamic policies of Zia and religious intolerance made this issue more prominent. Author has explained various social, economic and political implications of sectarianism. Muhammad Usman Amin Siddiqi \&Misbah Mukhtar in the article titled "Perception Of Violence And Victimization Among Hazaras in Pakistan (Journal of Political Science XXXIII,2015) has explained about violence against the Hazara community of Quetta and impact of violence on the Hazara people. It is also considered that states like India and Iran who do not want stable Pakistan are behind the killings of Hazaras. Because of sectarian clasehes Scattered Hazaras all around the Balochistan began to live together at Hazara Town.

\section{Research Methodology}

One precisely can define that research methodology is a determining tool of overall research. It provides guideline to conduct research in a precise way within certain limitations. Research is always conducted on certain parameters. Collection and nature of data also facilitate to adopt a specific methodology. There are two main techniques to conduct a research; qualitative and quantitative Quantitative data is all about numbers. Quantitative research involves a larger population more people means more data (Javaid, 2012).In the present research both these approaches have been applied by the researcher to evaluate data in a more comprehensive way. Researcher has used both primary and secondary sources to collect data. Primary source is more significant to collect more accurate information related to the issue and this source includes group discussions, interviews, distribution of questionnaire among targeted population and official documents. Secondary sources provide information through international and national journals, books, news papers and internet sources.

\section{Statistical Analysis Result and Discussions}

For collecting more accurate and concerned data researcher has conducted in-depth interviews and a survey from the Hazara community of Quetta in Balochistan. The population of the present study is students, young professionals, lawyers, doctors, bankers, teachers, leading figures of Hazara Democratic Party, labourers, vendors. Researcher under the quantitative approach has analyzed data through frequency table.

\section{Frequency Table 1}

\begin{tabular}{|l|l|l|l|l|l|}
\hline May In spite of military presence, Quetta one of the most insecure place in the country? \\
\hline & & Frequency & Percent & Valid Percent & Cumulative Percent \\
\hline \multirow{4}{*}{ Valid } & Neutral & 2 & 4.0 & 4.0 & 4.0 \\
\cline { 2 - 6 } & Disagree & 1 & 2.0 & 2.0 & 6.0 \\
\cline { 2 - 6 } & Agree & 32 & 64.0 & 64.0 & 70.0 \\
\cline { 2 - 6 } & Strongly Agree & 15 & 30.0 & 30.0 & 100.0 \\
\cline { 2 - 6 } & Total & 50 & 100.0 & 100.0 & \\
\hline
\end{tabular}

The above table shows that $4 \%$ of the respondents were neutral, $2 \%$ of the respondents were disagreeing, $64 \%$ were agreed and $30 \%$ were strongly agreed on the statement that In spite of overwhelming military presence, Quetta may be one of the most insecure places in the country. Majority of the respondents were agreed on that Quetta may be one of the most insecure places in the country. Respondents were conveying their sense of dissatisfaction towards the policies of the government regarding ensuring security in Quetta.

\section{Frequency Table 2}




\begin{tabular}{|l|l|l|l|l|l|}
\hline & & Frequency & Percent & Valid Percent & Cumulative Percent \\
\hline \multirow{5}{*}{ Valid } & Agree & 10 & 20.0 & 20.0 & 20.0 \\
\cline { 2 - 6 } & Strongly Agree & 40 & 80.0 & 80.0 & 100.0 \\
\cline { 2 - 6 } & Total & 50 & 100.0 & 100.0 & \\
\hline
\end{tabular}

The above table shows that $20 \%$ respondents were agreed and $80 \%$ respondents were strongly agreed on that Hazara community as a minority of Quetta feel its survival endanger so majority of the respondents were strongly agreed that their future in Quetta is not secure. Most of the students' respondents were worried about their future in Quetta. According to them after completing their master degree what they will do in Quetta as for as their professional life is concerned.

\section{Frequency Table 3}

\begin{tabular}{|l|l|l|l|l|l|}
\hline Do Hazara have their due share in administrative set up of Quetta ? \\
\hline \multirow{3}{*}{ Valid } & & Frequency & Percent & Valid Percent & Cumulative Percent \\
\cline { 2 - 6 } & neutral & 9 & 18.0 & 18.0 & 18.0 \\
\cline { 2 - 6 } & S.D & 2 & 4.0 & 4.0 & 22.0 \\
\cline { 2 - 6 } & Disagree & 8 & 16.0 & 16.0 & 38.0 \\
\cline { 2 - 6 } & Agree & 23 & 46.0 & 46.0 & 84.0 \\
\cline { 2 - 6 } & Strongly Agree & 8 & 16.0 & 16.0 & 100.0 \\
\cline { 2 - 6 } & Total & 50 & 100.0 & 100.0 & \\
\hline
\end{tabular}

The above table shows that $18 \%$ respondents were neutral, $4 \%$ were strongly disagree, $16 \%$ were disagree, $46 \%$ were agreed and $16 \%$ were strongly agreed on the statement that Hazara have their due share in administrative set up of Quetta. Majority of the respondents were agreed that Hazara have their due share in administrative set up of Quetta. According to various categories of the respondents they have satisfaction regarding their participation in various administrative departments of Quetta.

\section{Frequency Table 4}

\begin{tabular}{|l|l|l|l|l|l|}
\hline Is core identity of hazara endanger in Quetta? \\
\hline \multirow{3}{*}{ Valid } & neutral & 1 & 2.0 & 2.0 & Cumulative Percent \\
\cline { 2 - 6 } & Disagree & 1 & 2.0 & 2.0 & 2.0 \\
\cline { 2 - 6 } & Agree & 16 & 32.0 & 32.0 & 4.0 \\
\cline { 2 - 6 } & Strongly Agree & 32 & 64.0 & 64.0 & 36.0 \\
\cline { 2 - 6 } & Total & 50 & 100.0 & 100.0 & 100.0 \\
\hline
\end{tabular}

The above table shows that $2 \%$ respondents were neutral, $2 \%$ respondents were disagree, $32 \%$ respondents were agreed and $62 \%$ respondents were strongly agreed on the statement that core identity of Hazara is endanger in Quetta. Most of the student respondents showed their concern regarding presence of threat for their core identity. According to them their different features of face become a source to identify them as they are from Hazara community and easily they can be made a target by other sectarian identities. Students said they have to wear veil to hide their identity.

Frequency Table 5

\begin{tabular}{|l|l|l|l|l|l|}
\hline Is Hazra Democratic Party an organized voice of Hazara community of Quetta? \\
\hline \multirow{3}{*}{ Valid } & Neutral & Frequency & Percent & Valid Percent & Cumulative Percent \\
\cline { 2 - 6 } & S.D & 1 & 6.0 & 6.0 & 6.0 \\
\cline { 2 - 6 } & Disagree & 5 & 2.0 & 2.0 & 8.0 \\
\cline { 2 - 6 } & Agree & 34 & 68.0 & 10.0 & 18.0 \\
\hline
\end{tabular}




\begin{tabular}{|l|l|l|l|l|l|}
\hline Strongly Agree & 7 & 14.0 & 14.0 & 100.0 \\
\cline { 2 - 6 } & Total & 50 & 100.0 & 100.0 & \\
\hline
\end{tabular}

The above table shows that in response of the statement that Hazara Democratice party is an organized voice of Hazara community of Quetta 6\% respondents were neutral, 2\% respondents were strongly disagreed, $10 \%$ respondents were disagreed, $68 \%$ respondents were agreed and $14 \%$ respondents were strongly agreed that Hazara Democratic party is an organized voice of Hazaras. According to various categories of respondents this party has been playing a vital role for the protection of rights of Hazara community. This party is a strong voice for conveying the demands of Hazara community towards the ruling authority.

\section{Frequency Table 6}

\begin{tabular}{|l|l|l|l|l|l|}
\hline Are The concerns of Hazara community not properly addressed by the government? \\
\hline \multirow{3}{*}{ Valid } & & Frequency & Percent & Valid Percent & Cumulative Percent \\
\cline { 2 - 6 } & S.D & 3 & 6.0 & 6.0 & 6.0 \\
\cline { 2 - 6 } & & & & & \\
\cline { 2 - 6 } & Disagree & 1 & 2.0 & 2.0 & 8.0 \\
\cline { 2 - 6 } & Agree & 38 & 76.0 & 76.0 & 84.0 \\
\cline { 2 - 6 } & Strongly Agree & 8 & 16.0 & 16.0 & 100.0 \\
\cline { 2 - 6 } & Total & 50 & 100.0 & 100.0 & \\
\hline
\end{tabular}

The above table shows that in response of the question about the concerns of Hazara community are properly taken into consideration by the concerned authority and government in the real sense address the actual issues of this Shia community. 6\% respondents were strongly disagreed with this statement and $2 \%$ were disagreed. The overwhelming response of different individuals from Hazara community with reference of this statement was yes. $76 \%$ respondents showed their agreement regarding this statement. They were of the view that various ruling authorities did not bother to initiate accurate policies to resolve genuine issues of Hazara community of Quetta. 16\% respondents were strongly agreed with this question.

\section{Frequency Table 7}

\begin{tabular}{|l|l|l|l|l|l|}
\hline Are Hazara living in isolation in Quetta? & \multicolumn{4}{l|}{} \\
\hline \multirow{4}{*}{ Valid } & Neutral & Frequency & Percent & Valid Percent & Cumulative Percent \\
\cline { 2 - 6 } & Disagree & 2 & 4.0 & 4.0 & 4.0 \\
\cline { 2 - 6 } & Agree & 20 & 2.0 & 2.0 & 6.0 \\
\cline { 2 - 6 } & Strongly Agree & 27 & 40.0 & 40.0 & 46.0 \\
\cline { 2 - 6 } & Total & 50 & 54.0 & 54.0 & 100.0 \\
\hline
\end{tabular}

Frequency table 7 shows that in response of the question are Hazara living in isolation in Quetta 54\% respondents were strongly agreed regarding living in isolation issue. They have stated that their residential areas are separate from rest of the population of Quetta. According to them majority of Hazara population have been living in Hazara town and Mari Abad in Quetta. After many suicide incidents against Hazara community now government have taken various initiatives to provide them security to some extent. Young female students of Hazara community showed their reservations regarding their strict security orbit. They stated that they want to move freely but because of their prominent features which express they are Hazara Shia, they feel highly insecure to move according to their will. $40 \%$ respondents were agreed regarding this issue of isolation. 4\% respondents remained neutral regarding this question and $2 \%$ respondents were disagreed with this statement and they stated we do not think we are living in isolation. 


\section{Frequency Table 8}

\begin{tabular}{|l|l|l|l|l|l|}
\hline Are Economic interests of Hazara community safe in Quetta \\
\hline & & Frequency & Percent & Valid Percent & Cumulative Percent \\
\hline \multirow{4}{*}{ Valid } & Neutral & 3 & 6.0 & 6.0 & 6.0 \\
\cline { 2 - 6 } & S.D & 8 & 16.0 & 16.0 & 22.0 \\
\cline { 2 - 6 } & Disagree & 34 & 68.0 & 68.0 & 90.0 \\
\cline { 2 - 6 } & Agree & 4 & 8.0 & 8.0 & 98.0 \\
\cline { 2 - 6 } & Strongly Agree & 1 & 2.0 & 2.0 & 100.0 \\
\cline { 2 - 6 } & Total & 50 & 100.0 & 100.0 & \\
\hline
\end{tabular}

Frequency table 8 explains that $68 \%$ respondents have expressed their discontent regarding safety of economic interests of Hazara community in Quetta. They stated that sense of insecurity do not let them to utilize various economic opportunities. They prefer to invest outside the country. Most of the population if they have skill and knowledge they prefer to go abroad to avail different opportunities. $16 \%$ percent respondents were strongly disagreed regarding secure economic interests. They have said that Hazara community do not feel comfortable to have economic interaction with the local population. They feel their business; their economic interests are not safe in Quetta. 8\% respondents were satisfied regarding safety of their economic interests in Quetta. $2 \%$ respondents were strongly agreed with security of their economic interests and $6 \%$ respondents remained neutral regarding this statement.

\section{Frequency Table 9}

\begin{tabular}{|l|l|l|l|l|l|}
\hline \multicolumn{6}{|c|}{ Is Religious militancy affecting negatively to Hazara community of Quetta? } \\
\hline & & Frequency & Percent & Valid Percent & Cumulative Percent \\
\hline \multirow{3}{*}{ Valid } & Neutral & 1 & 2.0 & 2.0 & 2.0 \\
\cline { 2 - 6 } & Agree & 18 & 36.0 & 36.0 & 38.0 \\
\cline { 2 - 6 } & Strongly Agree & 31 & 62.0 & 62.0 & 100.0 \\
\cline { 2 - 6 } & Total & 50 & 100.0 & 100.0 & \\
\hline
\end{tabular}

The above table shows that in response of the question is religious militancy affecting negatively to Hazara community of Quetta? $62 \%$ respondents were strongly agreed regarding this question. According to them religious militancy has created serious distrust between local population and Hazara community. Hazara because of their distinctive features cannot hide their specific identity and because of this identification they become easy prey in the hands of opponent sect. they have a dominant threat of insecurity and remain unable to participate positively in the development of province. Though they are well educated and become successful to become part of different administrative posts. $36 \%$ respondents were agreed that religious militancy has been proving a major obstacle in the way of their development. While $2 \%$ respondents remained neutral regarding this statement.

\section{Frequency Table 10}

\begin{tabular}{|c|c|c|c|c|c|}
\hline \multicolumn{6}{|c|}{$\begin{array}{l}\text { Can Media play an effectiv } \\
\text { communities of Quetta? }\end{array}$} \\
\hline & & Frequency & Percent & Valid Percent & Cumulative Percent \\
\hline \multirow[t]{6}{*}{ Valid } & Neutral & 10 & 20.0 & 20.0 & 20.0 \\
\hline & S.D & 6 & 12.0 & 12.0 & 32.0 \\
\hline & Disagree & 6 & 12.0 & 12.0 & 44.0 \\
\hline & Agree & 25 & 50.0 & 50.0 & 94.0 \\
\hline & Strongly Agree & 3 & 6.0 & 6.0 & 100.0 \\
\hline & Total & 50 & 100.0 & 100.0 & \\
\hline
\end{tabular}


The above table shows that in response of the question about the role of media in creating peace and harmony among various communities of Quetta 50\% respondent were agreed regarding the role of media. They stated that media should create a soft image of various religious communities of Quetta. Media should highlight in the true sense various concepts of Islamic teachings for example tolerance, peace, equality, brotherhood and human dignity. Media should create strong awareness about the concept of tolerance among various religious communities. So they can learn to tolerate each other belief system. $6 \%$ respondents were strongly agreed with significant role of media to create harmony. $12 \%$ were disagreed and $12 \%$ were disagreed with the role of media. They say government should initiate effective policies to create awareness through educating people so they would be able to make differentiation between right and wrong. While $20 \%$ respondents remained neutral regarding the role of Media.

\section{Frequency Table 11}

\begin{tabular}{|l|l|l|l|l|l|}
\hline Is future of Hazara community pessimistic in Quetta? \\
\hline & & Frequency & Percent & Valid Percent & Cumulative Percent \\
\hline \multirow{4}{*}{ Valid } & neutral & 1 & 2.0 & 2.0 & 2.0 \\
\cline { 2 - 6 } & Disagree & 9 & 18.0 & 18.0 & 20.0 \\
\cline { 2 - 6 } & Agree & 25 & 50.0 & 50.0 & 70.0 \\
\cline { 2 - 6 } & Strongly Agree & 15 & 30.0 & 30.0 & 100.0 \\
\cline { 2 - 6 } & Total & 50 & 100.0 & 100.0 & \\
\hline
\end{tabular}

Frequency table 11 shows that in response of the question regarding the future of Hazara community in Quetta 50\% respondents were agreed that they do not see any optimism regarding their presence in Quetta. Religious militancy always poses a serious threat to their lives. The element of satisfaction is disappearing from their lives. 30\% respondents were strongly agreed with the statement. There is hard need on the part of the federal as well as provincial governments to formulate a long run policy to address the menace of sectarianism. 18\% respondents were of the view that they feel a positive development in near future regarding the existence of Hazara community in Quetta and 2\% respondents remained neutral regarding this question.

\section{Frequency Table 12}

$\begin{aligned} & \text { Are people of Hazara community migrating from Quetta for the sake of their survival and } \\
& \text { economic well being? }\end{aligned}$
\begin{tabular}{|l|l|l|l|l|l|}
\hline \\
\hline \multirow{3}{*}{ Valid } & Frequency & Percent & Valid Percent & Cumulative Percent \\
\cline { 2 - 6 } & Deutral & 3 & 6.0 & 6.0 & 6.0 \\
\cline { 2 - 6 } & Aisagree & 1 & 2.0 & 2.0 & 8.0 \\
\cline { 2 - 6 } & Agree & 30 & 60.0 & 60.0 & 68.0 \\
\cline { 2 - 6 } & Strongly Agree & 16 & 32.0 & 32.0 & 100.0 \\
\cline { 2 - 6 } & Total & 50 & 100.0 & 100.0 & \\
\hline
\end{tabular}

Frequency table 12 shows that in response of the question are people of Hazara community of Quetta migrating for their survival and economic well being $60 \%$ respondents were agreed regarding this question. They stated those who can afford to go abroad for availing better opportunities regarding economic activities and for the welfare of their families they prefer to go and settled on permanent basis. $32 \%$ respondents were strongly agreed with this statement that to leave Quetta for a better future is very common trend among individuals of Hazara community. 2\% respondents were disagreed that it is not necessary to migrate for better future and survival. If government ensure peace among different communities of Quetta then Quetta can be a best place to live and 6\% respondents remained neutral regarding this question. 


\begin{tabular}{|l|l|l|l|l|l|}
\hline Are you satisfied by the efforts of Government of Pakistan to stop sectarian violence \\
\hline \multirow{3}{*}{ Valid } & neutral & Frequency & Percent & Valid Percent & Cumulative Percent \\
\cline { 2 - 6 } & Disagree & 3 & 6.0 & 6.0 & 6.0 \\
\cline { 2 - 6 } & Agree & 11 & 60.0 & 60.0 & 66.0 \\
\cline { 2 - 6 } & Strongly Agree & 6 & 22.0 & 22.0 & 88.0 \\
\cline { 2 - 6 } & Total & 50 & 12.0 & 12.0 & 100.0 \\
\hline
\end{tabular}

The above table shows that in response of the question do the people of Hazara community feel satisfaction over the efforts of government of Pakistan $60 \%$ respondents were disagreed regarding this question. According to them various governments did not realize the sensitivity of the issue. Sectarian violence takes place under the sense of hatred. When different sects do not tolerate each other and start to kill on the basis of minor differences. Survival in such societies becomes difficult. Different governments formulated short term policies to tackle the menace of sectarian violence. The government first evolves a policy to manage sectarian conflicts and then long run policies should be evolved to resolve the issue. $22 \%$ respondents were agreed regarding government initiatives to address the sectarian issues but say that concerned sects should be taken into confidence by the government at the time of formulation of policies. $12 \%$ respondents were strongly agreed regarding the arrangements of various governments to tackle the issue. While $6 \%$ respondents remained neutral.

\section{Frequency Table 14}

\begin{tabular}{|l|l|l|l|l|l|}
\hline \multicolumn{6}{|c|}{ Is Role of political parties satisfactory to minimize sectarian violence in Quetta? } \\
\hline \multirow{3}{*}{ Valid } & & Frequency & Percent & Valid Percent & Cumulative Percent \\
\cline { 2 - 6 } & neutral & 7 & 14.0 & 14.0 & 14.0 \\
\cline { 2 - 6 } & S.D & 8 & 16.0 & 16.0 & 30.0 \\
\cline { 2 - 6 } & Disagree & 26 & 52.0 & 52.0 & 82.0 \\
\cline { 2 - 6 } & Agree & 8 & 16.0 & 16.0 & 98.0 \\
\cline { 2 - 6 } & Strongly Agree & 1 & 2.0 & 2.0 & 100.0 \\
\cline { 2 - 6 } & Total & 50 & 100.0 & 100.0 & \\
\hline
\end{tabular}

Frequency table 14 shows that in response of question about the role of political parties to minimize sectarian violence in Quetta 52\% respondents were disagreed regarding satisfaction about the role of political parties to address the issue of sectarianism. They stated political parties in Pakistan work for the personal interests of leadership and do not bother about issue regarding national integration. Political parties have interaction with people only during the days of elections. After elections it is a kind of dream of people to see their leaders in their respective constituency. $16 \%$ respondents were strongly disagreed about the positive role of political parties to minimize sectarianism. $16 \%$ respondents were agreed that they are to some extent satisfied with the role of political parties to curb the menace of sectarian violence. $2 \%$ respondents were strongly agreed regarding the effective role of political parties. While $14 \%$ respondents remained neutral in this regard.

\section{Frequency Table 15}

\begin{tabular}{|l|l|l|l|l|l|}
\hline Is a viable strategy the need of the time to stop sectarian violence? \\
\hline \multirow{4}{*}{ Valid } & & Frequency & Percent & Valid Percent & Cumulative Percent \\
\cline { 2 - 6 } & neutral & 2 & 4.0 & 4.0 & 4.0 \\
\cline { 2 - 6 } & S.D & 3 & 6.0 & 6.0 & 10.0 \\
\cline { 2 - 6 } & Disagree & 1 & 2.0 & 2.0 & 12.0 \\
\cline { 2 - 6 } & Agree & 17 & 34.0 & 34.0 & 46.0 \\
\cline { 2 - 6 } & Strongly Agree & 27 & 54.0 & 54.0 & 100.0 \\
\cline { 2 - 6 } & Total & 50 & 100.0 & 100.0 & \\
\hline
\end{tabular}


The above table shows in response of the question about a viable strategy is required to stop sectarian violence 54\% respondents were strongly agreed regarding the need of a viable mechanism to contain sectarian violence. They stated that various governments should initiate a policy which can provide a conducive environment to all religious communities to live according to their own specific belief system and freely can celebrate their rituals. 34\% respondents were agreed with a durable strategy to stop sectarian violence. $6 \%$ respondents were strongly disagreed and $2 \%$ respondents were disagreed regarding the need of the strategy to contain sectarian violence. While $4 \%$ respondents remained neutral regarding this question.

\section{Conclusion}

Above available information are very important to show ground reality about the existing fear among the Shia Hazara community of Quetta regarding their survival in Pakistan. They want to play their constructive role in the development of the country by availing different opportunities. But when they will remain confining in specific areas because of certain security reasons then it becomes difficult for them to move freely and flourish their potential. Shia Hazara community is facing various psychological issues due to prevailing insecurity. This is the need of the time that government has to take initiatives to curb those elements of society which are responsible to initiate sectarian attacks against the Shia Hazara community of Quetta. Goverment has to provide them justice so that Hazara community can feel itself an important part of political system of Pakistan and can remain positive in the progress of country.

\section{References:}

Ahmad, K. (2011). Sectarian War Pakistan's Sunni-Shia Violence and its Links to the Middle East. Karachi, Oxford University Press.

Ahmad (Jullundhri), Rashid. (1998) Islam and Current Issues, Lahore, Institute of Islamic Culture.

Mahmood, Sohail ,(1995). Islamic Fundamentalism in Pakistan, Egypt and Iran, Lahore, Vanguard.

NCHR Report. (2018).Understanding the agonies of ethnic Hazaras. (2018) National Commission for Human Rights. Retrieved from https://nchr.gov.pk/wp-content/uploads/2019/01/HAZARA-REPORT.pdf

Jalazai, M..K (1993). Sectarianism and Politico-Religious Terrorism in Pakistan, Lahore, Tarteeb Publishers.

Lieven, A. (2012). Pakistan a Hard Country, New Delhi: Penguin Books

Jalazi, M.K. (2006). Suicide Terrorism Taliban, Cross Border Terrorism and Violence in Pakistan and Afghanistan, Lahore, Institute of Advance and Strategic Studies.

Hussain, Z. (2010) The Scorpion Tail The Relentless Rise Of Islamic Militants in Pakistan -and How It Threatens the World, New York, Free Press

Manger, Leif. Ed (1999) Muslim Diversity: Local Islam in Global Context, Routledge

Huma Yousaf. (2012). Sectarian violence; Pakistan Greatest Security Threat? Norway, Norwegian Peace Building Resource Center. NOREF.

Ullah, Farman. (2009) in the article titled "Sectarianism in Pakistan: Causes \& Remedies" Pakistan, No. $43 \& 44$ (Spring \& Autumn) Pakistan Study Centre, University of Peshawar, ISSN:1990-6579

Mahsood, Asma Khan, (2017). in the article titled "History of Sectarianism in Pakistan: Implications for Lasting Peace in Journal of Political Science \& Public Affairs Vol.5, Issue 4.

Siddiqi ,Muhammad Usman Amin \& Mukhtar, Misbah (2015). in the article titled "Perception Of Violence And Victimization Among Hazaras in Pakistan in Journal of Political Science XXXIII. Javaid Umbreen, (2012).Academic Research Writing and Publishing. Lahore. Classic Punblication. 